\title{
UNDERSTANDING FARMERS' RESPONSE TO CLIMATE VARIABILITY IN NIGERIA: A MULTINOMIAL LOGIT APPROACH ${ }^{*}$ IKHELOA, E.E., ${ }^{1}$ IKPI A.E., ${ }^{2}$ AKINYOSOYE, V .0. ${ }^{2}$ and OLUWATAYO I.B. ${ }^{2}$ http://dx.doi.org/10.4314/ejesm.v6i6.6
}

Received 21st June 2013; accepted 25th September 2013

\begin{abstract}
In Nigeria, farming still depends largely on nature and therefore, vulnerable to climate variability. Climate variability affects production in a number of ways such as uncertainties with the onset of the farming season, flooding and drought in some areas. Farmers have responded by using adaptation strategies. The determinants of farmers' use of these strategies have not been adequately ascertained. In this study, farmers 'response to climate variability was examined. Primary and secondary data were used. A multi-stage sampling procedure was adopted in the collection of the primary data using structured questionnaires. Four vegetation zones out of seven where farming is mainly carried out were selected for the study. Using a list of farmers from the Agricultural Development Project, 470 farmers were randomly selected based on probability proportionate to the number of farmers in each vegetation zone. They were administered structured questionnaire. Data collected included socio-economic characteristics of the farmers, adaptation strategies they used and constraints associated with them. Data on climate were collected from Nigeria Meteorological Station, Oshodi. Data were analyzed using descriptive statistics, and multinomial logit models. Farmers used multiple adaptation strategies; Crop Diversification (CD), Soil Conservation Techniques (SCT) and Different Planting and Harvesting Dates (DPHD). Increase in farm size increased the likelihood of using CD (0.2741), DPHD (0.3240) and SCT (0.2741). Increases in temperature, cloud cover and sunshine decreased the likelihood of using crop diversification $(0.3001,0.0246$ and 0.0703 respectively), different planting and harvesting dates $(0.2113,0.1085$ and 0.1024 respectively) and soil conservation techniques $(0.6131,0.4311$ and 0.7219 respectively). However, increase in precipitation increased the likelihood of using crop diversification (0.1924), different planting and harvesting dates (0.1413) and soil conservation techniques (0.3410) Adaptation strategies would cushion the harmful effects of increase in precipitation. Farmers should be encouraged to use adaptation strategies to sustain output.
\end{abstract}

Key words: Climate Variability, Adaptation Strategies, Vegetation Zones, Nigeria

\section{Introduction}

Climate variability has become a serious issue in Nigeria. It affects food production in a number of ways such as uncertainty on the onset of the farming season which leads to a sequence of planting and replanting, and occurrence of extreme weather events (thunderstorms, flooding and drought). Imo and Nsa (2010) for example, observed that in the last twenty years, Northern Nigeria has witnessed four severe droughts, frightening dust storms and three killer floods. Similarly, in the last three years, the Southern and Eastern parts of the country have experienced unprecedented floods which left many dead and farms worth millions of naira destroyed. These have adverse impact on food production and supply. According to Sivakumar (1997), climate affects the various aspects of plant growth and yield and the effect of climate elements and their extreme include the significant alteration of crop productivity. Consequently, farmers face the prospect of tragic crop failure, reduced agricultural productivity, increased hunger, malnutrition and diseases (Zoellick, 2009).This explains why farmers are now abandoning farming for non farming activities (Apata et al., 2010).

A number of factors have been suggested to be responsible for climate variability. These

\footnotetext{
${ }^{1}$ Department of Agric. Economics \& Extension,

Ambrose Alli University Ekpoma, Edo State, Nigeria

${ }^{2}$ Department of Agric. Economics, University of Ibadan, 
factors include variations within the earth's climate, non climate factors and the activities of human beings (IPCC, 2001). Food crop production is important to the Nigeria economy in that it provides income to the farmers, food for man and livestock and employment opportunities to a vast majority of the rural dwellers. However, the food crop sub sector is threatened by climate variability. Loss of coastal lands resulting from sea level rise, land degradation (from erosion) and loss of soil fertility (from increased aridity) reduce the availability of economic lands for food production. Thus the farmer bears the burden of low productivity, low income and low capability to respond to the challenges.

Government has attempted to assist the farmer by putting in place some programmes aimed at encouraging farmers to use adaptation strategies to cushion the impacts of climate variability. The extent to which farmers have employed these strategies deserves to be examined in order to justify government's efforts. In addition, a better understanding of farmer perception of climate variability, present adaptation measures and their determinants will be important to inform policy for future successful adaptation of the agricultural sector.

It is in the light of this that this paper examines the response of farmers to climate variability. Specifically, the study seeks to determine: the level of awareness and perception of climate variability among farmers, identify the various adaptation strategies used by them as well as the constraints they face in using them. In addition, it examines the factors that influence the farmers' choice of the adaptation strategies they use.

\section{Materials and Methods \\ Study Area}

Nigeria is the study area. It is located between latitudes $4^{\circ}$ and $14^{\circ}$ and longitudes $24^{\circ} 51^{\prime}$ and $14^{\circ} 30^{\prime} \mathrm{E}$. It has a population of over 160 million people (NPC, 2006). The climate varies from humid tropical in the South to sub humid in the North and it is characterized by strong latitudinal zonation which progressively becomes drier as one move northward from the coast, (Metz, 1991). It is characterized by high temperature regime almost throughout the year except during the harmattan period. The predominant soils are the deeply weathered ferrallitic soils and the ferruginous tropical soils, (Aregheore, 2009). Over 60\% of the population is engaged in agriculture yet the country is food deficit and had on occasions been dangerously dependent on food import.

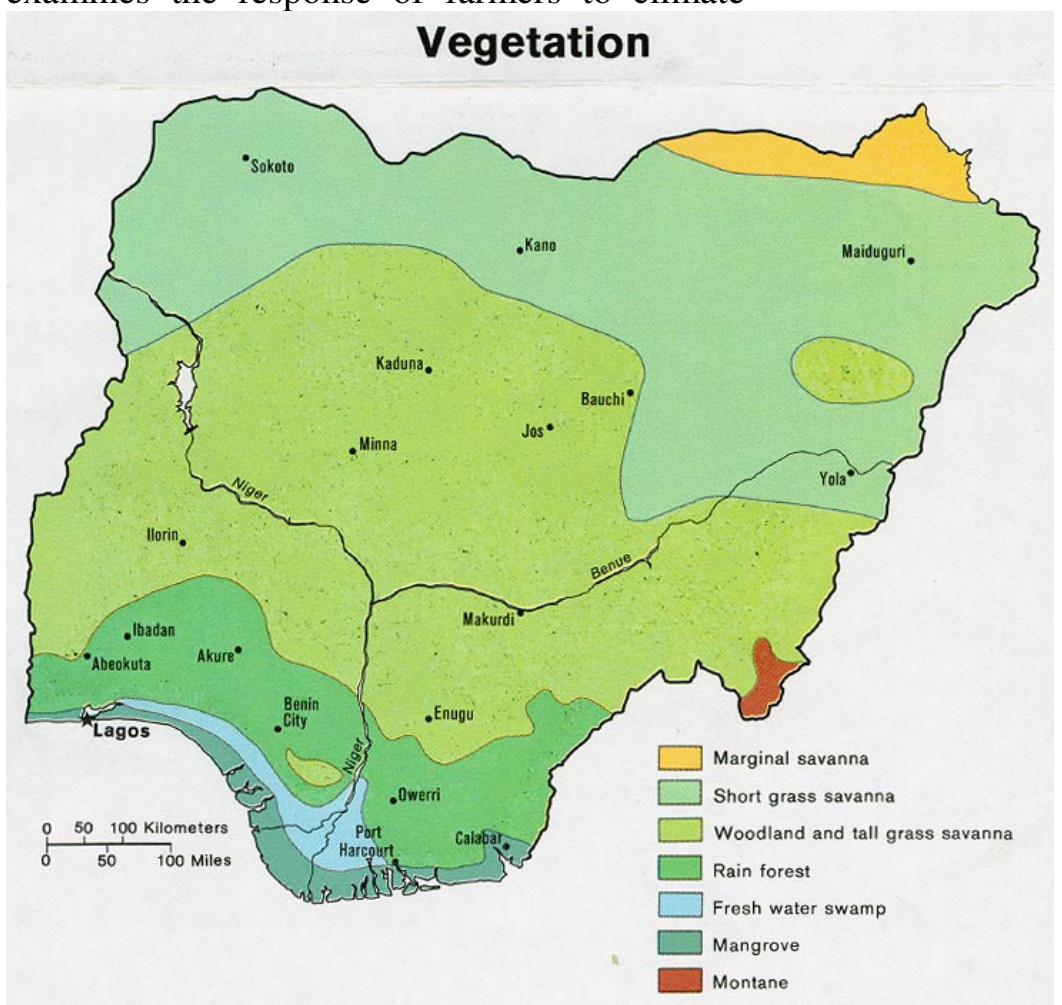

Figure1 Vegetation Map of Nigeria 
There are seven vegetation zones in Nigeria namely: marginal savannah, short grass savannah, woodland and tall grass savannah, rain forest, Fresh water swamp, mangrove and montane vegetation. (Wikipedia, 2010 and Eroaromi, 2009).

\section{Data collection}

Primary and secondary data were used. A multi-stage sampling procedure was adopted in the collection of the primary data using structured questionnaire. Four vegetation zones out of seven where farming is mainly carried out were selected for the study. Using a list of farmers from the Agricultural Development Project, 470 farmers were then randomly selected based on probability proportionate to the number of farmers in each vegetation zone. They were administered structured questionnaire. Data collected included socioeconomic characteristics of the farmers, adaptation strategies they used and constraints associated with their uses during 2009-2010 farming season. Secondary data on climate were collected from Nigeria Meteorological Station, Oshodi

\section{Data Analysis}

Data were analyzed using descriptive statistics (Tabulations, means, percentages, charts, and figures), Likert scale and multinomial logit models.

\section{Likert Scale}

This was used to measure the constraints farmers face in using adaptation strategies. Six (6) variables; inadequate funds, land tenure, poor information, labour, water and education were measured on a 4- point Likert scale with 4- ordered response levels (very serious, serious, not serious and undecided). The weighted mean score (2.5) was calculated as $\frac{4+3+2+1}{4}=2.5$. Any factor $\geq 2.5$ is considered serious.

\section{Multinomial Logit Model (MNL)}

This model was used to analyze factors that influenced the farmers' choice of adaptation strategies used in cushioning the impacts of climate variability in the study area. The dependent variables were adaptation strategies already adopted and these were grouped into the following: crop diversification, different planting and harvesting dates, changing use of chemical, soil conservation techniques, "other adaptations" and "no adaptation".

The explanatory variables for the MNL were the socio-economic characteristics of the farmers and climate attributes (mean annual temperature, precipitation, cloud cover and sunshine). The advantage of MNL is that it permits the analysis across more than two categories, allowing the determination of choice probabilities for different categories, (Ajibefun and Fatuase, 2011).

Let $\mathrm{Yi}$ be a random variable representing the adaptation categories or options chosen by any farming household taking on the values $(1,2, \ldots \ldots \ldots . . \mathrm{J})$ for $\mathrm{J}$, a positive integer and Let $\mathrm{X}$ represent a set of conditioning variables which were the household attributes like age, level of education, farm size, and experience.

The question of interest is how changes in the elements of $\mathrm{x}$ affect the response probabilities $P(Y=j / X), j=1,2 \ldots \ldots \ldots . J$

Since the probabilities must sum up to unity, $P(Y=j / X)$ is determined once the probabilities for $\mathrm{j}=2 \ldots \ldots \ldots \ldots . . \mathrm{J}$ are known.

Let $\mathrm{X}$ be a $1 \mathrm{x} \mathrm{K}$ vector with first element unity The MNL model has response probabilities $\mathrm{P}(\mathrm{Y}=\mathrm{j} / \mathrm{X})=\exp (\mathrm{X} \beta \mathrm{j}) /\left[1+\sum \exp (\mathrm{X} \beta \mathrm{h}), \mathrm{j}=\right.$

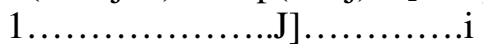

Where $\quad h \neq 1$

$\beta \mathrm{j}$ is $\mathrm{K} x \mathrm{1}, \mathrm{j}=1 \ldots \ldots \ldots \ldots \ldots . . \mathrm{J}$

Note that unbiased and consistent parameter estimates of the MNL model in equation (i) requires the assumption of independence of irrelevant alternatives (HA) to hold which means that the probability of employing an adaptation measures of a given household needs to be independent from the probability of choosing another adaptation method (that means $\mathrm{Pj} / \mathrm{Pk}$ is independent of the remaining probabilities). The premise of the HA assumption is the independent and homoscedastic disturbance terms of the basic models.

\section{Results and Discussion \\ Socio-economic Characteristics of the Respondents}

The respondents in the study area differ in socio-economic characteristics. Data in Table 1 
indicate that 408 (86.81 percent) of the respondents were male while only 62 (13.19 percent) were female. The average age of the farmer is $53.83 \pm 3.02$ years. They were not adequately educated. Twenty one farmers (4.47 percent) did not attend any formal educational institution, 154 farmers (32.77 percent) had primary education while 271 farmers (57.66 percent) had secondary school education. Only 24 farmers (5.11 percent) had tertiary education. Also, $380(80.85 \%)$ of them were married.

The respondents maintained fairly large families (average household size is 8). The farmers were not too wealthy, for example, of the 470 respondents, only 232 (209 males and 23 females) representing 49.36 percent were the owners of their farm land. 238 respondents (199 males and 39 females) were not owners of the farm-land they cultivated. They were mainly tenants or had the farm plots leased to them. The mean farming experience was 20.396 \pm 5.02 years.

Access to farm credit was poor among the respondents as 124 of them had no access to farm credit. Access to formal extension services by the farmers was also poor. (41.49\% of them had no access to formal extension services).

Table 1 Socio- economic Characteristics of the Respondents in the study area

\begin{tabular}{lccccc}
\hline Characteristics & Frequency & Mean & Percentage & Min. & Max. \\
\hline Male & 408 & & 86.81 & & \\
Female & 62 & & 13.19 & & 76 \\
Age (years) & & 53.83 & & 21 & \\
Married & 380 & & 80.85 & & \\
No formal education & 21 & & 4.47 & & \\
Primary education & 154 & & 32.77 & & \\
Secondary education & 271 & & 57.66 & & \\
Tertiary education & 24 & & 5.11 & & \\
Household size & & 8 & & & \\
Owned farmland & 232 & & 49.36 & & \\
Rented farmland & 238 & & 50.64 & & \\
Farming experience & & 20.39 & & & \\
Access to farm credit & 346 & & 73.62 & & \\
No access to formal credit & 124 & & 26.38 & & \\
Access to extension & 275 & & 58.51 & & \\
No access to extension & 195 & & 41.49 & & \\
Adopted adaptation strategy & 324 & & 68.94 & & \\
Did not adopt adaptation strategy & 146 & & 31.06 & & \\
\hline
\end{tabular}

\section{Awareness and Perception of Climate Variability}

Although climate variability has been a topical issue at international levels, it is only recently that it assumed a national outlook in Nigeria. In fact, this started with the establishment of the first Nigerian government body (Nigeria's Clean Development Mechanism National Authority) charged with the responsibility of finding ways to adapt to and mitigate the impacts of climate change in March, 2004 (CIDA, 2003). Since then the issue of climatic variability has assumed an important position in public discourse and media. However, the level of awareness of variability among the respondents varied across the vegetation zones. This is shown in figure 2

It is observed that the respondents from the montane vegetation zone were most aware of climate variability. Indeed, 92 percent of them were aware of climate variability. This is followed by those in the, woodland and tall grass vegetation zone (72\%), short grass savannah vegetation zone $(65 \%)$ and freshwater swamp (38 percent) respectively. Surrounded by mountains, the montane vegetation zone presents harsh conditions for agriculture. Therefore, the respondents from this zone must use adaptation measures to sustain their yield hence the high awareness of climate variability. 
The perception of the respondents with respect to changes in long - term climatic variables of rainfall, cloud cover, sunshine and

$\%$ Awareness

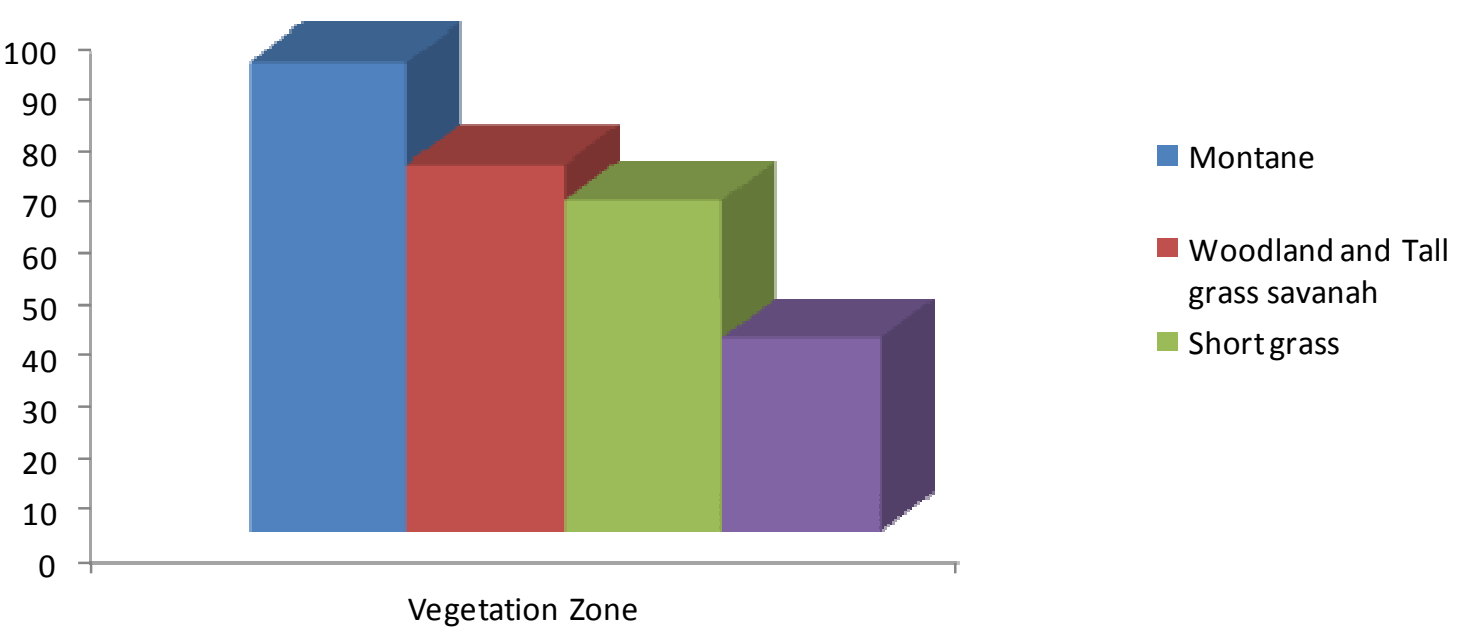

Figure 2 Awareness based on vegetation zones

$\%$ Perception

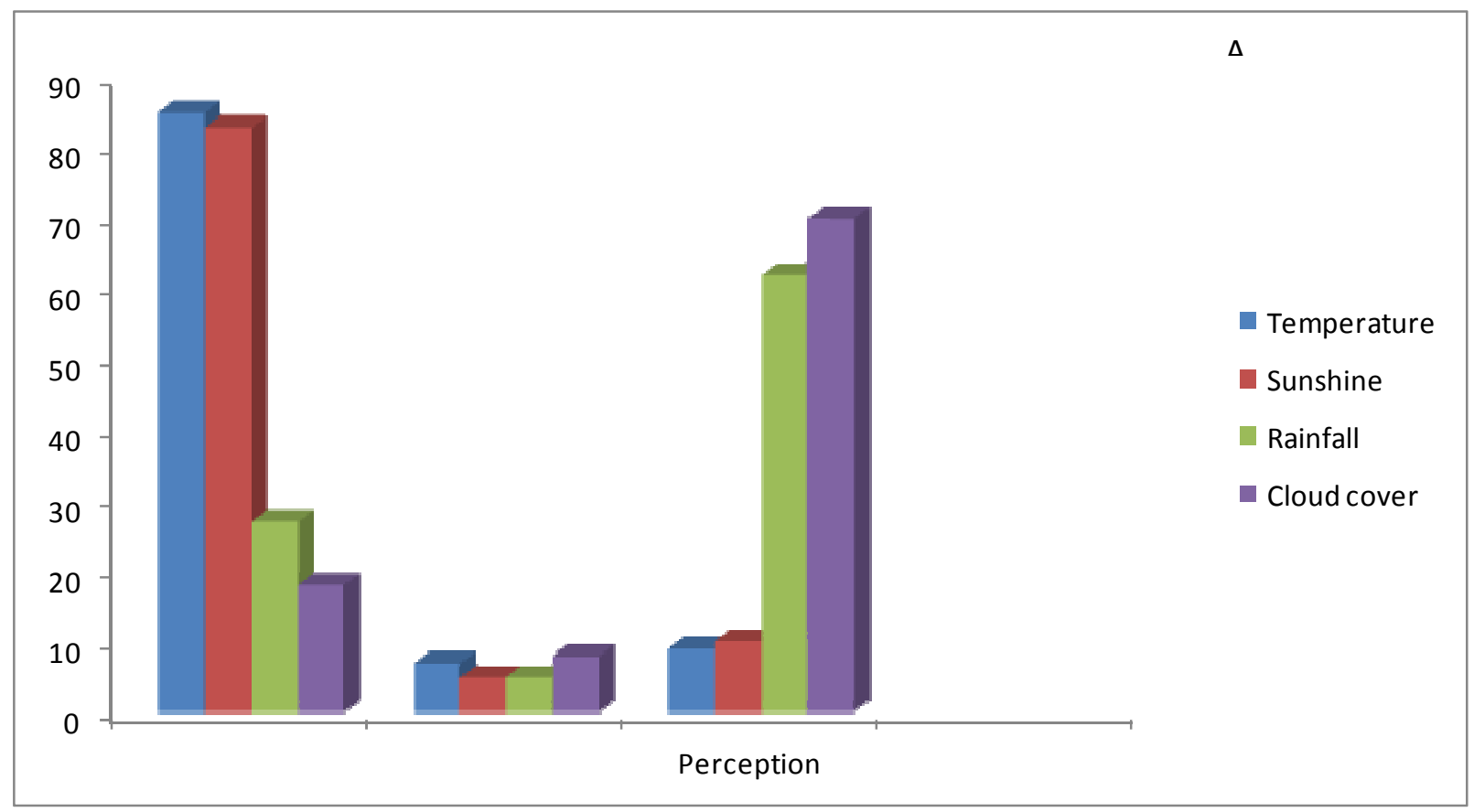

Figure 3Perception of respondents with respect to long term changes in climate variables. 
It is observed in figure 3 that 89 percent of the respondent's perceived annual average temperature over a long period of time as increasing, $88 \%$ of them noted that the number of sunshine hours on long term basis was increasing, 30 percent of the respondents observed that rainfall was increasing and 20 percent noticed that cloud cover was increasing. This pattern of observation may be related to the declining yield of crops experienced by them. Similarly, 7 percent of the respondents suggested that temperature was decreasing annually, 10 percent suggested that long-term sunshine hours were decreasing, 68 percent stated that rainfall was decreasing and 75 percent of them observed that cloud cover was also decreasing. Furthermore, 4 percent of the respondents did not observe changes in longtem temperature, 2 percent of them observed no changes in sunshine and rainfall while 5 percent of the respondents observed no changes in cloud cover. These findings agree with similar findings of Tunde (2011) who observed that farmers perceive changes in climate variables differently.

The perception of changes in climate variables by the respondents would be a major determinant of their responses. If they believe that rising temperatures and decreasing rainfall were responsible for the low yield of crops or crop failure, they are most likely to seek for and use adaptation strategies to cushion the harmful effects (Nhemachema and Hassan 2007)

\section{Types of Adaptation Strategies Used by the Respondents}

The adaptation strategies used by the respondents can be grouped into the following: Crop diversification, changing planting and harvesting dates, changing use of chemicals, Soil conservation measures, and other adaptation measures. Crop diversification involves planting different crops in order to avoid the possibility of total crop failure. Different varieties of crops were also planted by the respondents. Adjusting both the planting and harvesting dates of crops was adopted by the respondents as a way of taking advantage of favourable weather condition as the climate changes. It enables the farmers to plant and harvest either earlier or later than the usual pattern. In addition to the use of these strategies, farmers from time to time changed the types of chemicals used in their farms. Such chemicals include herbicides, pesticides, fertilizers and fungicides.

The soil conservation measures employed by the farmers include those of reducing use of heavy machinery, crop rotation, cautious use of fertilizers, mixed farming, and irrigation, mulching and planting of trees. Planting of trees was employed to reduce both wind and water erosion. Other adaptation measures include such measures as bush fallowing, migration, praying, and fasting. Some of the respondents refused to use any adaptation measures identified earlier.

\section{Determinants of Adaptation Strategies Used}

As indicated earlier, a multinomial logistic regression (MNL) was run to ascertain the determinants of the use of adaptation strategies. The results of the MNL analysis are presented in Table 2.

The respondents used multiple adaptation strategies; Crop Diversification (CD), Soil Conservation Techniques (SCT) and Different Planting and Harvesting Dates (DPHD). All $\mathrm{CD} / \mathrm{SCT} / \mathrm{DPHD}$ were used by 263 farmers (55.96\%). Both CD/SCT were used by 150 farmers $(31.92 \%)$ and $\mathrm{CD}$ alone was used by 57 farmers $(12.13 \%)$.

Data in Table 2 indicate that male-headed household has the tendency to adopt climate adaptation strategies much more than the female headed household. Generally, gender has a positive relationship with the use of crop diversification strategy, different planting and harvesting dates, changing use of chemicals, and soil conservation techniques. It has negative relationship with the use of other adaptation strategies. Other adaptation strategies include those of bush fallowing, migration, praying, and fasting.

It is also observed that farm size has a positive and significant relationship with the use of crop diversification, different planting and harvesting dates and soil conservation strategies. For example, as the farm size increases, the tendency to use crop diversification, different planting and harvesting dates and soil conservation techniques increases. 
Table 2 Results of the Multinomial Logit model

\begin{tabular}{|c|c|c|c|c|c|c|c|c|c|c|}
\hline $\begin{array}{l}\text { Explanatory } \\
\text { variable }\end{array}$ & $\begin{array}{c}\text { Crop } \\
\text { Diversification }\end{array}$ & & $\begin{array}{c}\text { Different } \\
\text { planting \& } \\
\text { harvesting } \\
\text { date }\end{array}$ & & $\begin{array}{l}\text { Changing } \\
\text { use of } \\
\text { Chemicals }\end{array}$ & & $\begin{array}{c}\text { Soil } \\
\text { conservation }\end{array}$ & & $\begin{array}{c}\text { Other } \\
\text { Adaptations } \\
\text { eg bush } \\
\text { burning, } \\
\text { Praying \& } \\
\text { fasting } \\
\end{array}$ & \\
\hline & Coefficient & $\begin{array}{c}\text { Marginal } \\
\text { Effect }\end{array}$ & Coefficient & $\begin{array}{c}\text { Marginal } \\
\text { Effect }\end{array}$ & Coefficient & $\begin{array}{c}\text { Marginal } \\
\text { Effect }\end{array}$ & Coefficient & $\begin{array}{c}\text { Marginal } \\
\text { Effect }\end{array}$ & Coefficient & $\begin{array}{c}\text { Marginal } \\
\text { Effect }\end{array}$ \\
\hline Gendermal() & $\begin{array}{l}3.14248 \\
(0.073)^{*}\end{array}$ & 2.1478 & $\begin{array}{c}2.241382 \\
(0.058)^{*}\end{array}$ & 2.1633 & $\begin{array}{l}2.763421 \\
(0.014)^{* *}\end{array}$ & 2.5321 & $\begin{array}{c}1.362413 \\
(0.131)\end{array}$ & 1.2350 & $\begin{array}{c}-23.5624 \\
(0.528)\end{array}$ & -23.5400 \\
\hline $\begin{array}{l}\text { Household } \\
\text { size }\end{array}$ & $\begin{array}{c}0.1693432 \\
(0.077)^{*}\end{array}$ & 0.0574 & $\begin{array}{c}0.0524391 \\
(0.558)\end{array}$ & 0.0500 & $\begin{array}{c}0.1134625 \\
(0.253)\end{array}$ & 0.1021 & $\begin{array}{c}0.0462413 \\
(0.571)\end{array}$ & 0.0462 & $\begin{array}{c}0.369247 \\
(0.874)\end{array}$ & 0.3578 \\
\hline Age & $\begin{array}{c}0.1481002 \\
(0.086)^{*}\end{array}$ & 0.5212 & $\begin{array}{l}0.1913804 \\
(0.034)^{* *}\end{array}$ & 0.1911 & $\begin{array}{c}0.1165462 \\
(0.112)\end{array}$ & 0.1154 & $\begin{array}{c}0.0370121 \\
(0.611)\end{array}$ & 0.0361 & $\begin{array}{c}-5.49282 \\
(0.104)\end{array}$ & -5.4928 \\
\hline Education & $\begin{array}{c}0.3326418 \\
(0.704)\end{array}$ & 0.3451 & $\begin{array}{c}0.3455286 \\
(0.658)\end{array}$ & 0.3420 & $\begin{array}{c}0.7760805 \\
(0.357)\end{array}$ & 0.7423 & $\begin{array}{c}0.0852243 \\
(0.911)\end{array}$ & 0.0848 & $\begin{array}{c}-33.04822 \\
(0.415)\end{array}$ & -33.0012 \\
\hline $\begin{array}{c}\text { Farming } \\
\text { Experience }\end{array}$ & $\begin{array}{c}0.1344423 * * * \\
(0.214)\end{array}$ & 0.1124 & $\begin{array}{c}0.0862326 * * \\
(0.214)\end{array}$ & 0.07635 & $\begin{array}{c}0.0476721 * * \\
(0.005)\end{array}$ & 0.0421 & $\begin{array}{c}0.0162874 * * \\
(0.697)\end{array}$ & 0.0160 & $\begin{array}{c}4.812041 * * \\
(0.089)\end{array}$ & 4.7562 \\
\hline Land tenure & $\begin{array}{c}11.624814 \\
(0.872)\end{array}$ & 0.8521 & $\begin{array}{c}11.30543 \\
(0.936)\end{array}$ & 10.2355 & $\begin{array}{l}-1.332041 \\
(0.223)\end{array}$ & -1.3300 & $\begin{array}{c}0.310483 \\
(0.754)\end{array}$ & 0.3018 & $\begin{array}{c}-185.9214 * \\
(0.081)\end{array}$ & 179.2142 \\
\hline Farm Size & $\begin{array}{c}3.982142 * * * \\
(0.004)\end{array}$ & 0.3522 & $\begin{array}{c}3.670182 * * * \\
(0.007)\end{array}$ & 0.3240 & $\begin{array}{c}3.402781 * * \\
(0.078)\end{array}$ & 3.1931 & $\begin{array}{c}2.74368 * * \\
(0.086)\end{array}$ & 0.2741 & $\begin{array}{c}28.402362 * * \\
(0.561)\end{array}$ & 28.360 \\
\hline $\begin{array}{l}\text { Access to } \\
\text { Extension }\end{array}$ & $\begin{array}{c}0.188014 * * \\
(0.800)\end{array}$ & 0.1421 & $\begin{array}{c}0.8456802 * * \\
(0.459)\end{array}$ & 0.4453 & $\begin{array}{c}0.1006345^{* *} \\
(0.921)\end{array}$ & 0.1111 & $\begin{array}{c}0.1231641^{* * *} \\
(0.791)\end{array}$ & 0.4224 & $\begin{array}{c}102.4827 \\
(0.098)\end{array}$ & 102.1119 \\
\hline $\begin{array}{l}\text { Access to } \\
\text { credit }\end{array}$ & $\begin{array}{c}0.3262625 * * \\
(0.707)\end{array}$ & 0.3124 & $\begin{array}{c}0.7452480 * * \\
(0.824)\end{array}$ & 0.7413 & $\begin{array}{c}0.768421 * * \\
(0.426)\end{array}$ & 0.7451 & $\begin{array}{c}0.1007364 * * \\
(0.872)\end{array}$ & 0.1000 & $\begin{array}{c}0.3406243 \\
(0.642)\end{array}$ & 0.3400 \\
\hline $\begin{array}{l}\text { Household } \\
\text { Income }\end{array}$ & $\begin{array}{c}2.523212 \\
(0.543)\end{array}$ & 2.4258 & $\begin{array}{c}1.974251 * * \\
(0.623)\end{array}$ & 1.6651 & $\begin{array}{c}2.4321641 * * \\
(0.452)\end{array}$ & 2.4221 & $\begin{array}{c}1.734042 * * \\
(0.624)\end{array}$ & 1.7331 & $\begin{array}{c}-0.0013294 \\
(0.115)\end{array}$ & -0.0001 \\
\hline Precipitation & $\begin{array}{c}0.0197243^{* * *} \\
(0.924)\end{array}$ & 0.1924 & $\begin{array}{c}1.436521 * * \\
(0.075)\end{array}$ & 0.1413 & $\begin{array}{c}0.1780261 * * \\
(0.773)\end{array}$ & 0.1765 & $\begin{array}{c}0.341325^{* *} \\
(0.418)\end{array}$ & 0.3410 & $\begin{array}{c}49.40321^{* *} \\
(0.085)\end{array}$ & 49.4313 \\
\hline Temperature & $\begin{array}{c}-0.6097243^{* *} \\
(0.424)\end{array}$ & -0.3001 & $\begin{array}{c}-1.052033 * * \\
(0.067)\end{array}$ & -0.2113 & $\begin{array}{c}-0.974628 * * \\
(0.056)\end{array}$ & -0.9715 & $\begin{array}{c}0.6243472 * * \\
(0.187)\end{array}$ & -0.6131 & $\begin{array}{c}-74.46208 * * \\
(0.093)\end{array}$ & -74.3607 \\
\hline Cloud cover & $\begin{array}{c}-0.024681 * * \\
(0.342)\end{array}$ & -0.0246 & $\begin{array}{c}- \\
1.2468124 * * \\
(0.0627)\end{array}$ & -0.1085 & $\begin{array}{c}-0.246512 * * \\
(0.421)\end{array}$ & -0.2344 & $\begin{array}{c}-0.434127 * * \\
(0.425)\end{array}$ & -0.4311 & $\begin{array}{c}-23.684127 \\
(0.083)\end{array}$ & -23.6841 \\
\hline Sunshine & $\begin{array}{c}-0.7042541 * * \\
(0.446)\end{array}$ & -0.0703 & $\begin{array}{c}-1.072045^{* *} \\
(0.069)\end{array}$ & -0.1024 & $\begin{array}{c}-0.924681 * * \\
(0.061)\end{array}$ & -0.9215 & $\begin{array}{c}- \\
0.7344215^{* *} \\
(0.172)\end{array}$ & -0.7219 & $\begin{array}{c}- \\
65.252147 * * \\
(0.089)\end{array}$ & -65.2008 \\
\hline Constant & 16.89524 & & -23.19482 & & -3.462814 & & -3.254712 & & 290.0324 & \\
\hline
\end{tabular}

No of Observations: 470

Log Likelihood: -170.89286, Pseudo R ${ }^{2}$ : 0.4574, L-R X²: 188.18 
It did not have a significant relationship with other adaptation strategies such as bush fallowing, praying and fasting. Perhaps the farm size could increase farm revenue and this could encourage the use of these strategies. This finding is in agreement with the submission of Nhemachena and Hassan (2007) in a study of adaptation to climate variability in Southern Africa that the farm size is a major determinant of the use of adaptation strategies. The age of the household's head is also an important determinant in the use of adaptation strategies as indicated in Table 2. As the age of the household head increases, the tendency to use crop diversification, different planting and harvesting dates, soil conservation techniques (including mulching and planting of trees) increases significantly. Also it has a positive but insignificant relationship with changing use of chemicals.

The more educated the head of the household, the more likely he is to use the adaptation strategies except those of "other adaptation strategies". Education is generally believed to enhance the reasoning capability of an individual and enables him manipulate his environment to his own advantage. The more educated the household head is the more likely that he will understand the dangers of climate variability and seeks ways to reduce or eliminate them. Similarly, farming experience of the household head has a positive and significant relationship with the use of all the adaptation strategy except those of "other adaptations".

Apart from changing use of chemicals, soil conservation techniques (mulching, planting of trees) and "other adaptation", land tenure has positive relationship with all the adaptation strategies. Household size is another variable that influences whether to use adaptation strategies or not, as indicated in Table 2 . Household size positively, though not significantly affected the use of all the adaptation strategies including those of "other adaptation" such as praying and fasting. Also, it is observed that household income, access to credit and extension facilities positively increased the use of crop diversification, different planting and harvesting dates, changing use of chemicals, and soil conservation techniques.

Carefully looking at the data in Table 2, it will be observed that all the climate variables: temperature, precipitation, cloud cover and sunshine influenced the decision to use adaptation strategies. However, if temperature, cloud cover and sunshine increase, the respondents are not likely to adopt any of the adaptation strategies because they would still be able to maintain high yield and hence high income. But if these variables decrease they are likely to adopt all the adaptation strategies outlined in order to increase their output.

Increase in precipitation, was found to exhibit a positive relationship with the use of all the adaptation strategies implying that the farmers are likely to adopt them when precipitation increases. This appears to be unusual because increase in precipitation should naturally improve the condition of the crops which would therefore, enhance yield and output. This was not the case in this study. However, recent experiences (2009-2012) in Nigeria where rainfall which has been very high destroyed many hectares of farm land tend to support this observation. Indeed, farmers would readily adopt these adaptation strategies when precipitation increases so that they can maintain their output or better still increase it.

Carefully studying the results of the marginal impact analysis which is also shown in Table 2, it is observed that increase in farm size increased the likelihood of farmers using crop diversification (0.2741), different planting and harvesting dates (0.3240) and soil conservation techniques (0.2741). Increase in temperature, cloud cover and sunshine decreased the likelihood of using crop diversification (0.3001, 0.0246 and 0.0703 respectively), different planting and harvesting dates $(0.2113,0.1085$ and 0.1024 respectively) and soil conservation techniques (0.6131, 0.4311 and 0.7219 respectively). However, increase in precipitation increased the likelihood of using crop diversification (0.1924), different planting and harvesting dates (0.1413) and soil conservation techniques (0.3410). It is important to note that the likelihood ratio statistics which is indicated by 
$\mathrm{X}^{2}$ statistics (188.18) are highly significant $(\mathrm{p}$ $0.0001)$, suggesting that the model has a strong explanatory power. In all cases, the estimated coefficients are compared with the base category of 'no adaptation.'

\section{Constraints to use of Adaptation Strategies}

In order to assess the constraints to use of adaptation strategies the Likert scale approach was adopted. Table 3 shows that inadequate funds were not a serious constraint in adopting crop diversification, different planting and harvesting dates as well as the use of other adaptations. However, in the use of chemicals, soil conservation, techniques, inadequate funds were considered a serious constraint.

Land tenure was considered a serious constraint in the use of all the adaptation strategies except those of other adaptations. Similarly, poor information labour and water were considered serious constraints to use of all the strategies except those of other adaptations. Education was considered a serious constraint to the use of all the adaptation strategies. Education enhances one's ability to properly assess a situation note the challenges and strive to overcome them.

Table 3 Constraints to Use of Adaptation Strategies

\begin{tabular}{|c|c|c|c|c|c|}
\hline Constraints & $\begin{array}{l}00 \\
.0 \\
0 \\
0 \\
0 \\
0 \\
0 \\
0 \\
0 \\
0 \\
0 \\
0 \\
0\end{array}$ & 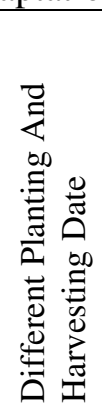 & 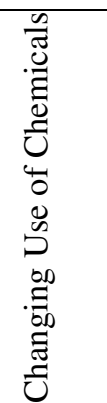 & 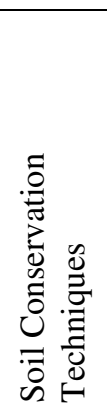 & 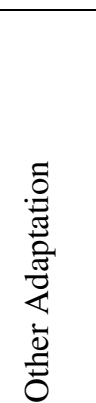 \\
\hline Inadequate Funds & 1.97 & 2.01 & $2.88 *$ & $2.92 *$ & 1.53 \\
\hline Land Tenure & $2.85^{*}$ & $2.92 *$ & 1.88 & $3.25 *$ & $3.02 *$ \\
\hline Poor Information & $3.51 *$ & $3.62 *$ & $3.15^{*}$ & $3.28 *$ & 1.18 \\
\hline Labour & $3.24 *$ & $2.87 *$ & $2.99 *$ & $2.68 *$ & 2.41 \\
\hline Water & $3.34 *$ & $3.57 *$ & $3.25 *$ & $3.45^{*}$ & 2.16 \\
\hline Education & $2.65 *$ & $2.60 *$ & $2.84 *$ & $2.80 *$ & $2.66^{*}$ \\
\hline
\end{tabular}

\section{Conclusion}

In response to climate variability, farmers used various adaptation strategies. Farmers' choices of these strategies were determined mainly by farm size, education, access to credit and extension and climatic factors. Improving farmers' access to credit and extension will boost their capability to use them and therefore sustain food production.

\section{References}

Ajibefun A.I. and Fatuase A.I. (2010), "Determinants of cassava farmers' strategies for adapting to climate change".

Apata, T. G., Ogunyinka, A., Sanusi, R. A. and Ogunwande, S. (2010), "Effects of Global climate change on Nigeria agriculture" An empirical analysis. Paper presented at the $84^{\text {th }}$ annual conference Agricultural Economic
Society held in Edinburgh, Scotland, Pp 345351

Aregheore, E.M. (2009), "Nigeria: Country Pasture/Forage Resource Profiles" www.fao.org/ag/agpc/doc/counprof/Nigeria/Nig eria.htm

CIDA. (2003), "Contribution to Global Effort to combat climate change (Nigeria)". http//www.axidicida.ge ca/CIDA WEB

Eroaromi, M.A (2009), "Country Pasture/ Forage Resource Profile. Nigeria"In F.A.O puplication.www.fao.org/ag/agi

Imo, J.E and Nsa, E. (2010), "Extreme climatic Variability in North-western Nigeria."An analysis of rainfall Trends and Patterns. Journal of Geography and Geology. Vol.3, No.1. sept. 2011

IPCC, (2001), "Climate Change: The Scientific Basis http//www.IPCC.ch 
Metz, H.C. (1991), "Nigeria: A country study. Washington": GPO for the Library of Congress 1991.

National Population Commission (2012),"Nigeria over 167 million populations": Implications and Challenges." www.population.gov'ng/index.php.

Nhemachema C. and S. Hansan (2007), "Determinants of African Farmers' Strategies for adapting to climate change: multinomial choice analysis

Rotimi, D. (2010), "Classification and Distribution of Nigerian vegetation". Skoola.com/lecture page
Tunde, A.M. (2011), "Perception of climate variability on agriculture and food security by men and women farmers in Idanre L.G.A, Ondo State, Nigeria" in Ethiopian Journal of Environmental Studies and Management. 4(2) Wikipedia (2013),"Geography of Nigeria"en.wikipedia.org/wiki/ geography of Nigeria vegetation

Zoellick, R.B. (2009), "A climate Smart Future." The Nation Newspaper,Vintage Press Limited, Lagos, Nigeria. Page 18 